\title{
PENGEMBANGAN SEKOLAH ALAM UNTUK MENINGKATKAN HASIL BELAJAR SISWA SEKOLAH DASAR PADA PELAJARAN IPA
}

\author{
Oleh: \\ Al Qari'ah, Dwi Surtini, Efan Efendi \\ Prodi Pendidikan IPA Fakultas Keguruan dan Ilmu Pendidikan \\ Universitas Wiraraja Sumenep
}

\begin{abstract}
ABSTRAK
Penelitian ini bertujuan untuk mendeskripsikan perkembangan minat belajar dan pengaruh sekolah alam terhadap hasil prestasi siswa SDN Daramista III pada pelajaran IPA. Jenis penelitian ini adalah penelitian campuran, perlakuan dengan mengajarkan pembelajaran IPA dengan pengembangan sekolah alam dianalisis secara deskriptif kualitatif sedangkan hasil belajar yang didapatkan dianalisis secara kuantitatif. Temuan yang dihasilkan dalam penelitian ini adalah Sekolah alam mampu meningkatkan minat belajar siswa terhadap pelajaran IPA. Diindikasikan dengan siswa tidak merasa bosan, senang mengikuti pelajaran, dan serius dalam kegiatan. Pengaruh sekolah alam terhadap hasil prestasi siswa cukup signifikan, sehingga menunjukkan bahwa sekolah alam pengaruhnya cukup baik dalam proses pembelajaran.
\end{abstract}

\section{Kata kunci : Sekolah Alam, Minat Belajar, Hasil Prestasi, Pelajaran IPA}

\section{PENDAHULUAN}

Kualitas sumber daya manusia di suatu daerah bahkan di sebuah negara tidak dapat dipisahkan dari besarnya peran pendidikan. Bangsa Indonesia yang merdeka sudah lebih dari setengah abad, kualitas sumber daya manusia masih terus kalah dengan bangsa yang kemerdekaannya dibelakang bangsa Indonesia karena faktor minimnya lembaga pendidikan yang bermutu (Bambang : 2002)

Indonesia telah banyak melakukan usaha, hal ini dapat dilihat dari banyak aspek, yaitu ditinjau dari jumlah guru, anak didik, lembaga pendidikan, kualitas pendidikan, dan sebagainya. Namun persoalannya sampai sekarang ini masih belum membuktikan pendidikan di Indonesia menjadi unggul dan berkualitas. Terbukti pendidikan kita belum sejajar di Asia apalagi di dunia.

Dari data Human Development Index yang dipakai sebagai dasar pertimbangan, menunjukkan perjuangan bangsa Indonesia dalam bidang pendidikan belum berhasil melahirkan generasi yang unggul. Lulusan pendidikan yang tidak siap pakai bahkan belum siap latih. Sehingga lulusan pendidikan Indonesia bukan menjadi pencipta lapangan kerja, melainkan menjadi pencari kerja.

Hasil pendidikan yang belum baik disebabkan oleh proses pembelajaran yang Puritanisme, yaitu pengelolaan pembelajaran yang berpusat pada guru; pembelajaran model pabrik, yaitu satu ukuran untuk semua yang kurang menghargai keanekaragaman siswa; proses pembelajaran terlalu verbal, artinya tidak mengajak anak pada mengalami; sejarah pengetahuan, yaitu terlalu terpaku pada kurikulum; penjara bagi siswa, yaitu proses belajar yang dijalani anak serba terpaksa, serta deployment of power, pemanggungan kekuasaan orang dewasa pada anak.

Sekolah seharusnya menjadi tempat yang menyenangkan bagi siswa, namun kenyataanya banyak siswa yang merasa jenuh, bosan, dan terpaksa duduk tertib berjam-jam di dalam kelas. Seyogyanya sekolah melakukan inovasi untuk meminimalisasi kelemahan pada sistem yang telah berjalan. Disekolah, siswa 
diharapkan belajar dengan riang gembira. Setiap topik dibahas secara komprehensif dari berbagai dimensi sesuai taraf pikir anak.

Keaktifan siswa akan dapat muncul ketika proses belajar mengajar menggunakan model yang sesuai untuk memfasilitasi siswa menjadi aktif. Siswa sekolah dasar yang tingkat usianya antara sekitar 7 - 13 tahun, sesuai dengan tingkat perkembangannya, memiliki karakter dasar yang aktif serta menyukai permainan dengan teman sebayanya. Karakteristik dasar ini sebaiknya dapat diakomodir dan diarahkan dalam proses belajar mengajar. Sehingga siswa merasa belajar bukan sebagai sebuah beban, melainkan suatu kegiatan menyenangkan tanpa paksaan.

Menurut kurikulum sekolah dasar saat ini (Kurikulum Tingkat Satuan Pendidikan 2006), Ilmu Pengetahuan Alam (IPA) di sekolah dasar berhubungan dengan cara mencari tahu tentang alam secara sistematis, sehingga IPA bukan hanya penguasaan sekumpulan pengetahuan yang berupa fakta-fakta, konsep-konsep, atau prinsip-prinsip saja tetapi juga merupakan suatu proses penemuan. Pendidikan IPA diharapkan menjadi wahana bagi peserta didik untuk mempelajari diri sendiri dan alam sekitar, serta prospek pengembangan lebih lanjut dalam menerapkannya di dalam kehidupan sehari-hari. Proses pembelajarannya menekankan pada pemberian pengalaman langsung untuk mengembangkan kompetensi agar menjelajahi dan memahami alam sekitar secara alamiah. Pendidikan IPA diarahkan untuk inkuairi dan berbuat sehingga dapat membantu peserta didik untuk memperoleh pemahaman yang lebih mendalam tentang alam sekitar (Permendiknas no.22 : 2006).

Kabupaten Sumenep merupakan miniatur dari kondisi pendidikan di Indonesia yang memprihatinkan, kondisi pembelajaran disekolah-sekolah pelosok pedesaan yang terjadi di SDN Daramista
III Kecamatan Lenteng Kabupaten Sumenep, misalnya. Proses belajar siswa tidak diarahkan pada konsep bahwa belajar akan lebih bermakna jika anak mengalami, bukan hanya mengetahui apa yang telah dipelajarinya. Pembelajaran diorientasikan pada target penguasaan materi, padahal hal tersebut terbukti berhasil dalam kompetisi mengingat jangka pendek saja tetapi gagal dalam membekali anak didik memecahkan persoalan dalam kehidupan jangka panjang.

Kehidupan yang semakin cenderung individualistik juga perlu di antisipasi dengan mengasah rasa tanggung jawab dan empati sosial melalui permainan dinamika kelompok, tutor sebaya, berinteraksi langsung dengan alam sehingga potensi anak sebagai makhluk sosial akan terbentuk. Dengan konsep belajar yang menyenangkan dan tidak membosankan, terbukti anak akan menikmati sekolah seharian penuh. Sehingga nantinya sekolah mampu melejitkan potensi yang dimiliki tiap-tiap anak secara beragam.

Dengan demikian sekolah alam dapat dijadikan sebuah alternatif dalam srategi belajar yang prinsipnya tidak perlu mengubah kurikulum untuk menerapkannya. Proses pembelajaran berlangsung alami dalam bentuk kegiatan siswa bekerja dan mengalami, bukan transfer pengetahuan dari guru ke siswa. Dengan harapan nantinya dapat dijadikan salah satu awal untuk memperbaiki dan mencari pemecahan terhadap permasalahan yang terjadi. Sehingga, dalam pelaksanaannya pada kegiatan belajar mengajar tidak mengalami hambatan. Khususnya pada materi pelajaran IPA yang dalam kenyataannya justru perlu untuk belajar menganalisa dengan kehidupan yang nyata. Sehingga wujud dari sekolah alam sangat dibutuhkan. 


\section{METODE PENELITIAN}

Jenis penelitian ini adalah campuran, yaitu deskriptif kualitatif dan kuantitatif. Tujuan jenis penulisan ini adalah untuk mendeskripsikan perkembangan minat belajar siswa SD terhadap pembelajaran IPA dengan sekolah alam serta pengaruhnya terhadap peningkatan hasil belajar siswa dengan metode sekolah alam yang dikembangkan. Subjek penelitian dalam pengembangan sekolah alam pada pembelajaran IPA ini adalah siswa SDN Daramista III Kecamatan Lenteng Kabupaten Sumenep.

Design penelitian ini adalah sebagai berikut.

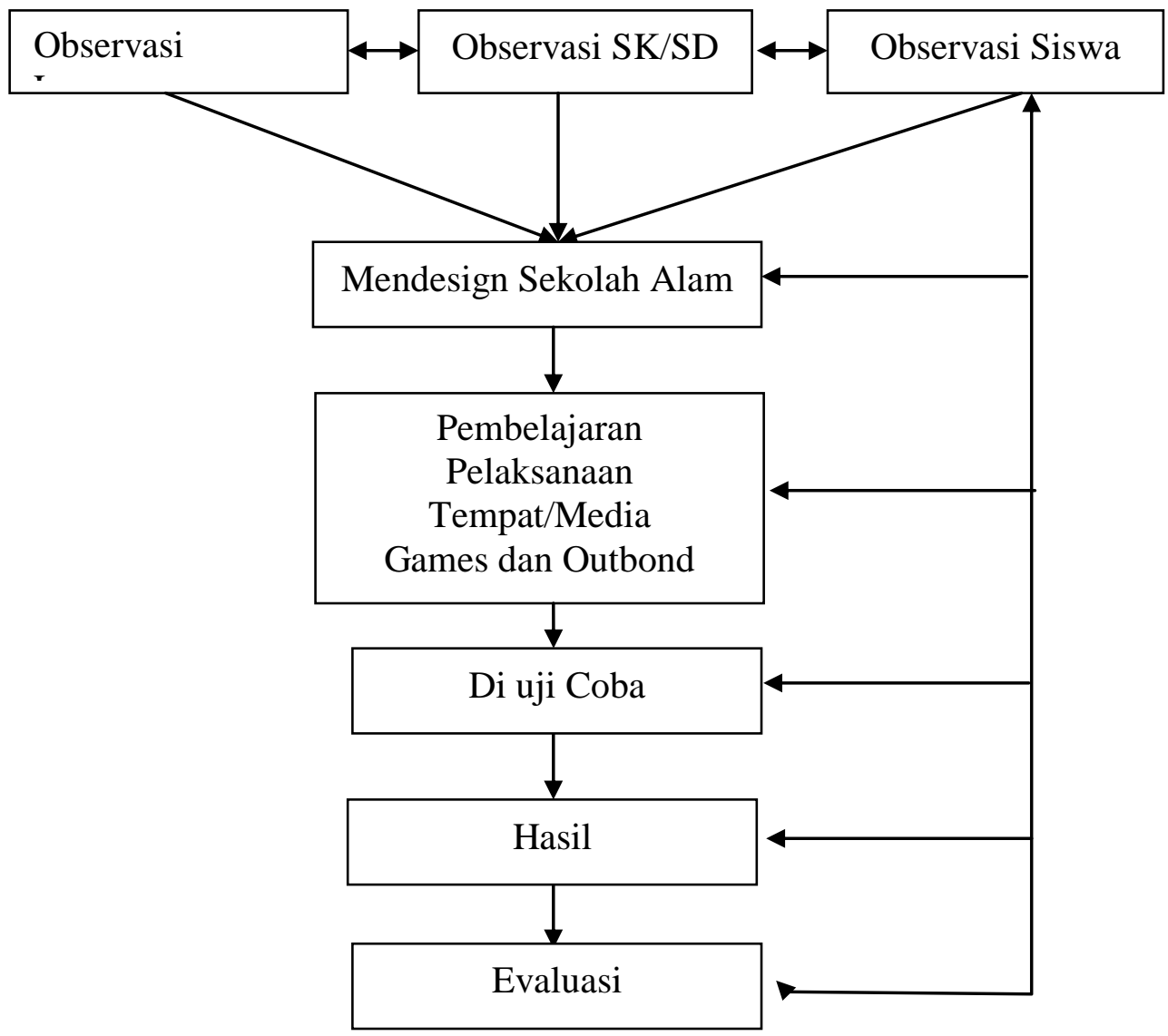

\section{HASIL DAN PEMBAHASAN}

Peningkatan Minat Belajar Siswa SDN Daramista III Lenteng Sumenep pada Mata Pelajaran IPA dengan Sekolah Alam

Munculnya sekolah alam memperoleh tanggapan yang cukup bervariasi. Proses belajar-mengajar di sekolah alam tidak dikungkung di dalam kelas melainkan berubah menjadi aktivitas kehidupan nyata yang dihayati dengan kegembiraan karena konsepnya diarahkan agar siswa dapat belajar sambil bermain. Hal itu sangat membantu anak-anak menikmati masa-masa awal pertumbuhan, dan membangun gambaran positif tentang kehidupan dan bumi yang dihuni, apalagi masih seusia anak SD yang pengetahuannya ada pada taraf operasional konkrit. Selain itu, gabungan antara pelajaran kelas, latihan outbound, penelitian lapangan (outing), market day, dan lainnya, telah memberikan pemahaman dan kesadaran yang relatif lebih utuh tentang kehidupan, membentuk struktur emosi dan mentalitas yang lebih stabil, serta membangun sikap-sikap keseharian yang lebih baik dari waktu ke waktu. Namun hal yang menjadi fokus pembahasan ini adalah pehamahaman 
terhadap pelajaran IPA yang salah satu cirinya adalah mengkonstruksi pengetahuannya bersifat alami dari alam.

Data hasil analisis, kegiatan sekolah alam sangatlah berpengaruh terhadap minat dalam memperoleh pembelajaran yang baik bagi individu para siswa. Indikator yang di pakai dalam melihat peningkatan minat belajar siswa adalah perhatian terhadap bahan pelajaran, memahami materi pelajaran dan menyelesaikan soal-soal pelajaran. Ketertarikan ataupun minat dibedakan menjadi ketertarikan terhadap sekolah alam itu sendiri atau rasa senang meliputi rasa senang mengetahui bahan belajar, memahami bahan belajar, dan kemampuan menyelesaikan soal-soal serta keseriusan siswa dalam mengikuti kegiatan sekolah alam dari awal sampai akhir kegiatan.

Data yang diperoleh atas peningkatan minat belajar siswa SDN Daramista III, Sekolah alam berhasil meningkatkan minat belajar siswa terutama pada pendidikan IPA, dilihat dari hasil dari respon siswa terhadap sekolah alam dan keseriusan siswa mengikuti sekolah alam. Data yang didapat dari hasil kegiatan pengabdian kepada masyarakat yang dilakukan selama satu setengah bulan pembelajaran dengan sekolah alam, dari 31 anak siswa yang menjadi peserta dalam sekolah alam, menunjukkan sekitar $16 \%$ saja selama pelaksanaan peserta tidak hadir. Selain itu, dibuktikan dari hasil respon langsung dan respon dalam quisioner, yaitu 24 responden (77\%) menyatakan sangat tertarik, 4 responden (13\%) menyatakan kurang senang, dan 3 responden (10\%) menyatakan tidak senang. Hal tersebut juga menunjukkan kondisi siswa yang antusias, bersemangat, dan tidak merasa dipenjarakan oleh kelas. Pembelajaran yang dirasanya tidak membuat mereka jenuh di dalam kelas mengindikasikan bahwa sekolah alam cukup memberikan alternatif untuk pembelajaran bahkan lebih luas lagi dapat membantu menguragi kerusakan alam dan menjaga ekosistem alam secara alami dan terdidik.

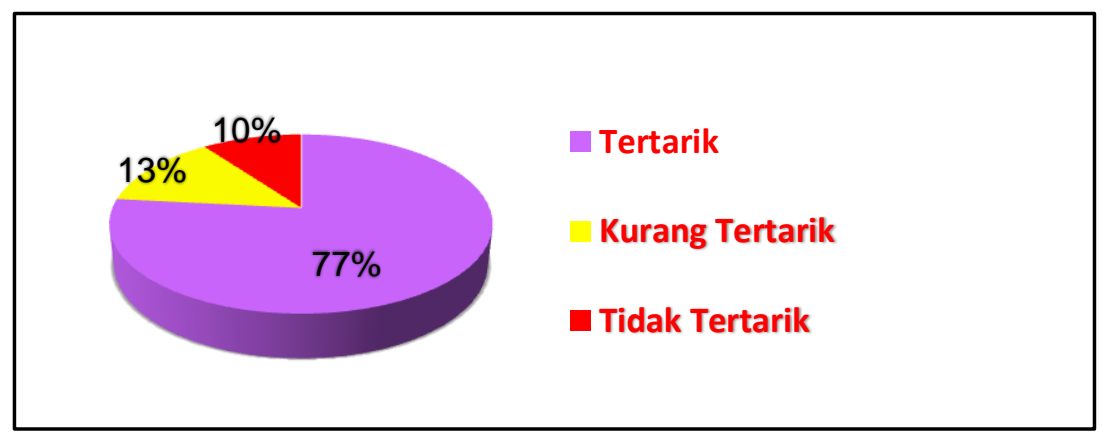

Gambar 1.1. grafik respon siswa terhadap sekolah alam

Selain itu, hasil wawancara pada saat kegiatan menunjukkan bahwa siswa senang mengikuti sekolah alam. Mereka merasa bebas dalam mengikuti pelajaran dan belajar sambil bermain menjadi konsep pembelajaran yang tidak menutup kemungkinan dapat disukai semua anak SD. Berikut komentar dari siswa SD Daramista yang mengikuti sekolah alam. "Saya senang mengikuti sekolah alam karena tidak bosan, belajarnya bebas, tidak disuruh menghafal pelajaran". (wawancara, 24 April 2011)

"Saya sangat suka belajar di sekolah alam, karena kami diajak belajar sambil bermain". (wawancara, 24 April 2011)

Dilihat dari sudut pandang yang berbeda bahwa pihak sekolah juga mendukung adanya keberlanjutan sekolah alam di SDN Daramista III. Hal ini terbukti dengan kesanggupan sekolah dan komite sekolah untuk menyediakan lahan 
yang akan digunakan untuk tempat kegiatan sekolah alam. Selain itu juga terbukti dengan hasil data kuisoner respon guru sebanyak 12 orang terhadap sekolah alam $(85 \%$ sangat mendukung, $15 \%$ mendukung, $0 \%$ biasa saja, 0\% tidak mendukung). Hal ini dapat diindikasikan bahwa keinginan agar kegiatan ini dilanjutkan sangat besar.

\section{Pengaruh Sekolah Alam terhadap Hasil} Prestasi Siswa SDN Daramista III Lenteng Sumenep

Minat sangat besar pengaruhnya terhadap hasil belajar, karena apabila bahan pelajaran yang dipelajari tidak sesuai dengan minat, siswa tidak akan belajar dengan baik sebab tidak menarik baginya. Bahan pelajaran yang menarik minat siswa, lebih mudah dipelajari sehingga dapat meningkatkan prestasi belajar.

Data yang diperoleh dari minat belajar mereka yang tinggi dalam mengikuti sekolah alam sangat berpengaruh pula pada kemampuan siswa untuk dapat dengan mudah memahami pelajaran IPA pada saat belajar. Dibuktikan adanya peningkatan yang cukup signifikan pada prestasi yang di dapat oleh siswa. Pada hasil ketuntasan belajar (teori) didapatkan data sebagai berikut.

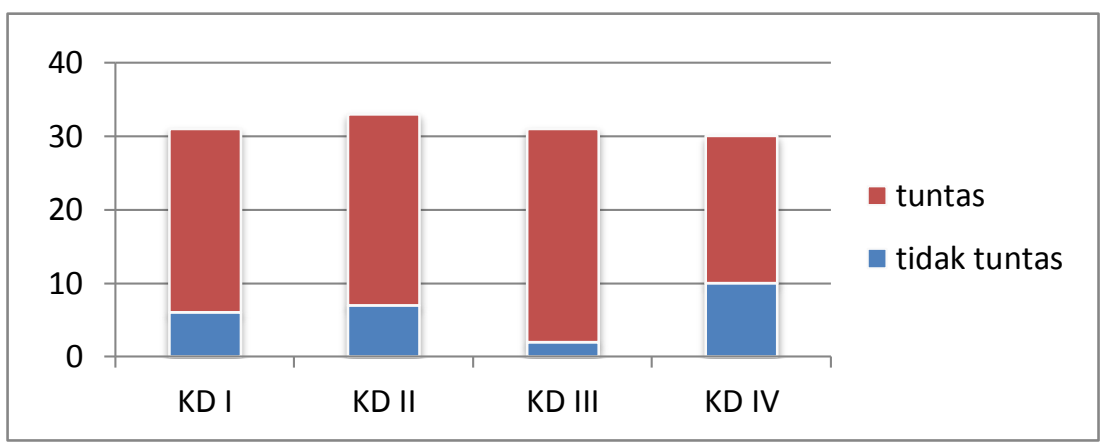

Gambar 1.2. Data Ketuntasan Belajar Siswa (Kognitif)

Rata-rata dari 31 siswa yang mengikuti sekolah alam, 20-29 orang yang dapat menuntaskan belajarnya dalam setiap kompetensi dasar yang diuji melalui test tulis. Selain itu, ketuntasan belajar praktek yang dibagi menjadi 4 kelompok dapat dilihat dari data hasil test observasi didefinisikan dalam data berikut.

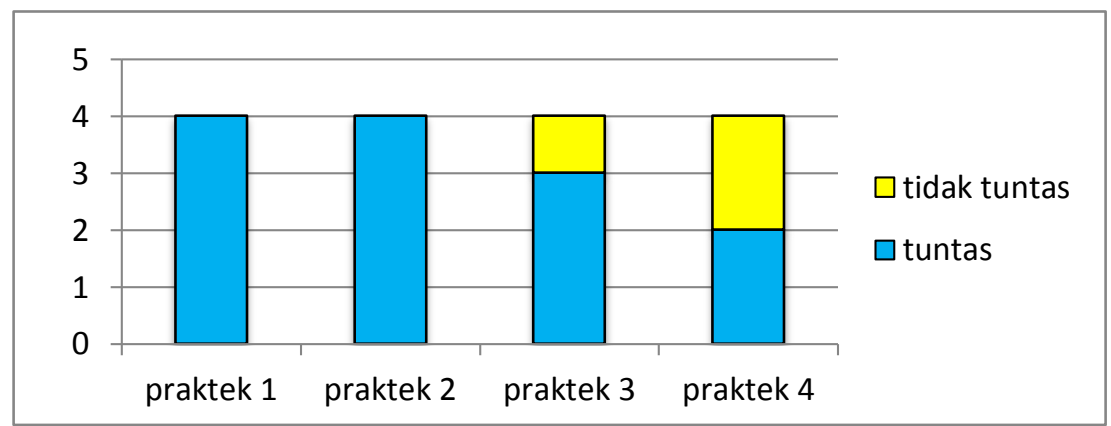

Gambar 1.3. Data Ketuntasan Belajar Siswa (Psikomotorik) 
Hal tersebut juga dapat dilihat dari hasil perbandingan data pre test yang diberikan yaitu $40 \%$ baik (11 orang), dan $60 \%$ tidak baik (19 orang), sedangkan post test yang diberikan menunjukkan $83 \%$ baik (26 orang), dan $17 \%$ tidak baik (5 orang).

Dari data diatas, di kategorikan nilai yang dikatakan baik melebihi nilai angka 50, sedangkan yang tidak baik yaitu yang mendapat nilai kurang atau sama dengan angka 50. Peningkatan tersebut, memberikan sumbangsih bahwa sekolah alam di butuhkan pada sistem pendidikan saat ini.

Pengaruh lain yang di lihat kebermanfaatannya, sekolah alam mampu memberikan kontribusi dan bisa diterapkan di sekolah saat pembelajaran IPA yang menuntut siswa belajar diluar kelas seperti kegiatan observasi dan lain sebagainya. Namun alangkah baiknya jika sekolah alam itu sendiri dapat dibangun secara independent demi menghadapi pendidikan masa depan.

\section{KESIMPULAN}

Simpulan yang dapat dihasilkan dari karya tulis ini adalah sebagai berikut.

1. Sekolah alam mampu meningkatkan minat belajar siswa SDN Daramista III Lenteng Sumenep terhadap pelajaran IPA. Di indikasikan dengan siswa tidak merasa bosan, senang mengikuti pelajaran, serius dalam kegiatan, dan antusias.

2. Pengaruh sekolah alam terhadap hasil prestasi siswa cukup signifikan, peningkatan hasil dari pre test dan post test mencapai $48 \%$, sehingga menunjukkan bahwa sekolah alam pengaruhnya cukup baik dalam proses pembelajaran.

DAFTAR PUSTAKA

Habibi. 2010. Pembelajaran IPA 1. Sumenep : Unija Press.
Hamalik, Oemar. 2003. Kurikulum dan Pembelajaran. Jakarta : Bumi Aksara.

Hartati, Nani. 2006. Gambaran Sikap Orang Tua terhadap Sekolah. (Online)

http://repository.usu.ac.id/bitstrea $\mathrm{m} / 123456789 / 14522 / 1 / 09 \mathrm{E} 00941$ .pdf. diakses pada tanggal 05 Desember 2011.

Mintaraga, Bambang. Dkk. 2008. PR Bahasa Indonesia 2B. Klaten : PT Intan Parawira.

Mulyasa. 2006. Kurikulum Tingkat Satuan Pendidikan. Surabaya : Agung Media Mulya.

Sharbinie, Muslihudin. TT. Sekolah Modern Berbasiskan Limbah dan Alam.

(Online)http://www.puslitjaknov. org/data/file/2008/makalah_peser ta/06_Muslihudin\%20Sharbinie_ SEKOLAH\%20MODERN\%20B ERBASISKAN\%20LIMBAH\%2 0DAN\%20ALAM\%20STUDI\% 20KASUS\%20.pdf. Diakses pada tanggal 05 Desember 2011.

Syarifuddin, Hidayat. Dkk. 2008. Sekolah
Alam sebagai Alternatif
Pendidikan Lingkungan dalam
Rangka mengatasi Krisis
Ekologi.
(Online)
http://repository.ipb.ac.id/bitstrea $\mathrm{m} /$ handle/123456789/33036/seko lah\%20alam\%20sebagai.pdf.
Diakses pada tanggal 05 Desember 2011.

Koesoema, D. (2007). Pendidikan karakter : Strategi mendidik anak di zaman global. Jakarta : Grasindo.

2011. (online)

http://aadesanjaya.blogspot.com/2011/03/ pengertian-definisi-hasil-belajar.html. diakses pada tanggal 06 Desember 2011. 